\title{
Hematobiochemical profile in Surti goats during post-partum period
}

Tanvi D. Manat, Sandhya S. Chaudhary, Virendra Kumar Singh, Sanjay B. Patel and Gopal Puri

Department of Veterinary Physiology and Biochemistry, College of Veterinary Sciences and Animal Husbandry, Navsari Agricultural University, Navsari - 396 450, Gujarat, India.

Corresponding author: Sandhya S. Chaudhary, e-mail: sandhyachaudhary6@gmail.com,

TDM: dr.tanvimanat@gmail.com, VKS: drvksingh1981@gmail.com, SBP: sbvet@nau.in, GP: drgopalpuri@gmail.com

Received: 26-07-2015, Revised: 10-11-2015, Accepted: 21-11-2015, Published online: 12-01-2016

doi: 10.14202/vetworld.2016.19-24 How to cite this article: Manat TD, Chaudhary SS, Singh VK, Patel SB, Puri G (2016)

Hematobiochemical profile in Surti goats during post-partum period, Veterinary World 9(1): 19-24.

\begin{abstract}
Aim: The study was undertaken to find out the changes in hematobiochemical profile in post-partum Surti goats.

Materials and Methods: The present study was conducted on 40 Surti goats out of which 20 goats who had undergone recent parturition acted as treatment group and 20 non-pregnant animals comprised control group. Blood samples were collected from the treatment group on $0,7,14,21,30$, and 45 days post kidding and once from the control group. Blood samples were analyzed for hematological parameters such as hemoglobin (Hb), packed cell volume (PCV), total erythrocyte count (TEC), total leukocyte count (TLC), differential leukocyte count, and biochemical metabolites such as total protein (TP), albumin, globulin, total cholesterol (TC), triglycerides (TG), non-esterified fatty acid (NEFA), glucose, and urea.
\end{abstract}

Results: $\mathrm{Hb}$ level was the highest on the $45^{\text {th }}$ day and lowest on the day of parturition. Significantly low level of $\mathrm{Hb}$, $\mathrm{PCV}$, and lymphocyte was found on 0 day and significantly high level was found on the $45^{\text {th }}$ day. TEC was also low on the 0 day and high on the $45^{\text {th }}$ day post kidding, but the difference was non-significant. Mid-sized cells and granulocyte percentage decreased significantly from 0 to $45^{\text {th }}$ day post-partum. TP, albumin, and urea were found to be lowest on 0 day and highest on $45^{\text {th }}$ day post-partum. Urea concentration increased parallel to TP indicating an increase in urea production with catabolism of protein. The globulin concentration also increased from 0 to $45^{\text {th }}$ day post-partum, but the difference was non-significant. TC, TG, and NEFA were the highest on 0 day and lowest on the $45^{\text {th }}$ day post-partum. Decrease in TC and TG from 0 to $45^{\text {th }}$ day post-partum indicates that the animals utilized the lipids for the supply of energy for milk production. High level of NEFA acts as an indicator of negative energy status but in the present study, the high glucose level on 0 day indicates that the animals were in positive energy status. The glucose concentration decreased up to $14^{\text {th }}$ day post-partum and then started increasing from $21^{\text {st }}$ day onward.

Conclusion: Hematobiochemical parameters are indicative of health status of animals. Significantly low values of $\mathrm{Hb}$, PCV, and TLC during first 2 weeks post-partum are indicative of stress. Catabolism of protein occurred during 2 weeks post-partum, as observed from increase in urea concentration. Decrease TGs and high level of NEFA during the transition period are suggestive of utilization of lipids for the supply of energy. High glucose level on 0 day indicates that the animals were in positive energy status.

Keywords: hematobiochemical parameters, post-partum period, Surti goat.

\section{Introduction}

India comprises of 135.17 million goat population out of which $3.67 \%$ belongs to Gujarat as per $19^{\text {th }}$ Livestock Census of the year 2012. Surti goat is a medium sized mostly stall-fed, non-nomadic in nature, dual purpose goat breed and found in small towns and cities. The breed is confined to the middle and south region of Gujarat state and neighboring areas of Maharashtra state up to Nasik district. Surti goats are famous for their fertility, prolificacy, meat and milk quality as well as adaptability to the hot humid condition. Goats have unique ability to adapt and maintain themselves in harsh environments and

Copyright: Manat et al. Open Access. This article is distributed under the terms of the Creative Commons Attribution 4.0 International License (http://creativecommons.org/licenses/by/4.0/), which permits unrestricted use, distribution, and reproduction in any medium, provided you give appropriate credit to the original author(s) and the source, provide a link to the Creative Commons license, and indicate if changes were made. The Creative Commons Public Domain Dedication waiver (http://creativecommons.org/ publicdomain/zero/1.0/) applies to the data made available in this article, unless otherwise stated. elicit great variation in hematological and biochemical parameters on the basis of the physiological phase of life even within the same breed. It has distinct social, economical, managerial, and biological advantages over other livestock species and often termed as the "poor man's cow."

Hematological parameters are good indicators of physiological health status, and its evaluation is important in assessing the response of animal to various physiological stressful conditions such as pregnancy, parturition, and lactation. Metabolites viz. total protein (TP), triglycerides (TGs), free fatty acids, and urea are important indicators of the health and nutritional status of the animals [1] and metabolic activity in lactating animals [2]. The post-parturient period is characterized by marked changes in an animal's endocrine and metabolic status as well as by reduction in feed intake when the nutrient demand for impending lactogenesis is increasing.

In spite of its good production potential, the Surti breed has been declared as an endangered breed since 80 's owing to its possibilities of extinction, but very 
little efforts are made toward its conservation as gazed by very few studies done on this precious goat breed of South Gujarat. Post-partum period, a part of the transition period, especially upto 45 days after parturition is the most stressful period because of the depressed feed intake and endocrine and metabolic changes at parturition and lactation. Optimal transition requires a comprehensive understanding of the hematobiochemical events occurring during the periparturient period. Breed to breed variation in hematobiochemical parameters during the transition period also occurs within the same species of the animal because of the climatic condition of the region of which animals are inhabitants.

The present study was therefore planned to get detailed information through frequently sampling on routinely measured hematological and biochemical analytes during the post-parturient period in Surti goats.

\section{Materials and Methods}

\section{Ethical approval}

The study was conducted following approved guidelines of the Institutional Animal Ethics Committee.

\section{Location of study and climatic conditions}

The present study was conducted in the Department of Veterinary Physiology and Biochemistry. The experimental animals were maintained at Livestock Research Station, Navsari Agricultural University, Navsari, which is geographically located approximately at an altitude of $11.89 \mathrm{~m}$ above mean sea level, at latitude of $20^{\circ}-57^{\prime} 0$ " North and longitude of $72^{\circ}-54^{\prime} 0$ " East. The climate of the area forms the part of the tropical and coastal area. In general, winter is cool and dry while summer and monsoon remain hot and humid. During the study period, temperature ranged from $31.4^{\circ} \mathrm{C}$ (maximum) to $17.5^{\circ} \mathrm{C}$ (minimum) and relative humidity ranged from $96.7 \%$ (maximum) to $39.7 \%$ (minimum).

\section{Experimental animals}

40 apparently healthy Surti goats (aged 36-51 months) were selected for the study and divided into two groups (treatment and control) of 20 each. All the goats were housed in pucca shed with concrete floor, and feeding was done as per the ICAR feeding standards, 1998. The duration of study in the treatment group was 45 days post-partum wherein blood was collected on the day of kidding, $7^{\text {th }}, 14^{\text {th }}, 21^{\text {st }}, 30^{\text {th }}$, and $45^{\text {th }}$ days post-partum. Blood was also collected once from control group which comprised of non-pregnant goats. Parity of all the goats ranged from first to sixth. Approximately $5 \mathrm{ml}$ of whole blood from each animal was collected from a jugular vein in $\mathrm{K}_{3}$ ethylenediaminetetraacetic acid vacutainers for hematological examination. Serum from clotted blood was separated by centrifugation at $3000 \mathrm{rpm}$ for $15 \mathrm{~min}$ and stored at $-20^{\circ} \mathrm{C}$ in deep freeze until analyzed for biochemical parameters.

\section{Hematological analysis}

Hematological parameters such as hemoglobin $(\mathrm{Hb})$, packed cell volume (PCV), total erythrocyte count (TEC), total leukocyte count (TLC), and differential leukocyte count were estimated by fully automated hematology cell counter (MEDONIC CA 620/530 VET).

\section{Biochemical analysis}

The biochemical metabolites were analyzed by the use of Randox kits on semi-automated clinical chemistry analyzer (Merck). The serum biochemical metabolites measured were TP $(\mathrm{g} / \mathrm{dl})$ by biuret method, albumin $(\mathrm{g} / \mathrm{dl})$ by bromocresol green dye binding method, globulin (g/dl), total cholesterol (TC) $(\mathrm{mg} / \mathrm{dl})$ by enzymatic endpoint method, TG $(\mathrm{mg} / \mathrm{dl})$ by glycerol-3-phosphate oxidase-trinder method, non-esterified fatty acid (NEFA) (mmol/L) by colorimetric method, glucose $(\mathrm{mg} / \mathrm{dl})$ by GOD-PAP method, and urea $(\mathrm{mg} / \mathrm{dl})$ by glutamate dehydrogenase method.

\section{Statistical analysis}

The collected data for all the parameters were analyzed using randomized block design [3].

\section{Results}

The values of different hematological parameters during the post-partum period on $0,7^{\text {th }}, 14^{\text {th }}, 21^{\text {st }}$, $30^{\text {th }}$, and $45^{\text {th }}$ days are given in Table- 1 . The analysis of variance (ANOVA) for different hematological parameters is presented in Table-2.

$\mathrm{Hb}$ level was significantly $(\mathrm{p}<0.01)$ different between the days and groups. The highest and lowest concentration of $\mathrm{Hb}$ was found on the $45^{\text {th }}$ day post-partum and on the day of kidding, respectively. PCV values increased significantly $(p<0.05)$ from 0 day to $14^{\text {th }}$ day. The TEC did not show significant differences during the post-partum period. Significantly $(p<0.01)$ low value of TLC was observed on 0 day but the difference was non-significant between the groups and from $7^{\text {th }}$ to $45^{\text {th }}$ day post-partum. Lymphocyte $\%$ increased from the lowest value on 0 day to highest value on $45^{\text {th }}$ day post-partum and showed a significant $(p<0.01)$ difference between treatment and control group. However, the descending trend was observed for the MID\% and granulocyte \% from 0 to $45^{\text {th }}$ day post-partum.

The values for all hematological parameters in both the groups were in normal range except GRAN\% which was slightly lower on $45^{\text {th }}$ day post-partum.

The values of different biochemical parameters viz. TP, albumin, globulin, TC, TG, glucose, NEFA, and urea during the post-partum period are presented in Table-3. The ANOVA for different biochemical parameters is presented in Table-4.

$\mathrm{TP}$ and albumin concentration increased significantly $(p<0.01)$ from 0 to 14 days as well as on $45^{\text {th }}$ day post-partum. Globulin increase was non-significant during the study. Similar values were observed between control and treatment groups on 
Table-1: Hematological profile (mean \pm SE) in Surti goats during the post-partum period.

\begin{tabular}{|c|c|c|c|c|c|c|c|c|}
\hline Parameters & 0 day & 7 day & 14 day & 21 day & 30 day & 45 day & Control & $\begin{array}{c}\text { Reference } \\
\text { values }\end{array}$ \\
\hline $\mathrm{Hb}(\mathrm{g} / \mathrm{dl})$ & $6.10 \pm 0.13^{a}$ & $7.32 \pm 0.07^{b}$ & $8.09 \pm 0.09^{c}$ & $8.52 \pm 0.07^{d}$ & $9.16 \pm 0.06^{e}$ & $9.54 \pm 0.08^{f}$ & $10.18 \pm 0.22^{\mathrm{h}}$ & $8-12$ [22] \\
\hline PCV (\%) & $17.13 \pm 0.29^{a}$ & $22.66 \pm 0.53^{b}$ & $23.90 \pm 0.47^{c}$ & $24.02 \pm 0.34^{c}$ & $24.49 \pm 0.36^{c}$ & $24.82 \pm 0.42^{c}$ & $26.64 \pm 0.32^{d}$ & $22-38[22]$ \\
\hline $\begin{array}{l}\text { TEC } \\
\left(\times 10^{6} / \mathrm{mm}^{3}\right)\end{array}$ & $13.10 \pm 0.43$ & $13.13 \pm 0.57$ & $13.27 \pm 0.55$ & $13.49 \pm 0.81$ & $13.71 \pm 0.56$ & $13.99 \pm 0.48$ & $14.12 \pm 0.27$ & $8-18[22]$ \\
\hline $\begin{array}{l}\text { TLC } \\
\left(\times 10^{3} / \mathrm{mm}^{3}\right)\end{array}$ & $10.56 \pm 0.43^{a}$ & $12.04 \pm 0.52^{\mathrm{ab}}$ & $12.99 \pm 0.63^{b}$ & $12.75 \pm 0.54^{b}$ & $12.47 \pm 0.65^{b}$ & $12.26 \pm 0.57^{b}$ & $12.31 \pm 0.32^{\mathrm{b}}$ & $4-13[22]$ \\
\hline LYM (\%) & $51.80 \pm 0.36^{a}$ & $55.65 \pm 0.57^{b}$ & $59.00 \pm 0.55^{c}$ & $61.95 \pm 0.46^{d}$ & $64.50 \pm 0.35^{e}$ & $66.85 \pm 0.25^{f}$ & $51.95 \pm 0.39^{a}$ & $50-70[22]$ \\
\hline MID (\%) & $5.90 \pm 0.24^{\mathrm{e}}$ & $5.80 \pm 0.22^{\mathrm{e}}$ & $4.80 \pm 0.16^{c}$ & $4.05 \pm 0.18^{b}$ & $3.90 \pm 0.18^{\mathrm{ab}}$ & $3.50 \pm 0.11^{\mathrm{a}}$ & $4.95 \pm 0.25^{c d}$ & $0-4[22]$ \\
\hline GRAN (\%) & $42.30 \pm 0.42^{f}$ & $38.55 \pm 0.58^{\mathrm{e}}$ & $36.20 \pm 0.51^{d}$ & $33.90 \pm 0.54^{c}$ & $31.70 \pm 0.39^{b}$ & $29.65 \pm 0.27^{a}$ & $32.40 \pm 0.43^{b}$ & $30-48$ [22] \\
\hline
\end{tabular}

Mean bearing different superscript differ significantly. $\mathrm{Hb}=$ Hemoglobin, $\mathrm{PCV}=$ Packed cell volume, TEC=Total erythrocyte count, TLC=Total leukocyte count, SE=Standard error

Table-2: Analysis of variance for hematological parameters.

\begin{tabular}{|c|c|c|c|c|c|c|c|c|}
\hline \multirow{2}{*}{$\begin{array}{l}\text { Source of } \\
\text { variation }\end{array}$} & \multirow[t]{2}{*}{ df } & \multicolumn{7}{|c|}{ Mean sum of square } \\
\hline & & Hb & HCT & TEC & TLC & LYM & MID & GRAN \\
\hline Treatment & 6 & $38.65 * *$ & $180.45 * *$ & 3.35 & $12.43 *$ & $710.33 * *$ & $17.42 * *$ & $382.67 * *$ \\
\hline Error & 133 & 0.27 & 3.16 & 5.99 & 5.74 & 3.72 & 0.77 & 4.22 \\
\hline
\end{tabular}

$* \mathrm{p}<0.05, * * \mathrm{p}<0.01 . \mathrm{Hb}=$ Hemoglobin, PCV=Packed cell volume, TEC=Total erythrocyte count, TLC=Total leukocyte count

$30^{\text {th }}$ and $45^{\text {th }}$ day post-partum for TP and $21^{\text {st }}$ day and $45^{\text {th }}$ day post-partum for albumin. TG values were significantly $(\mathrm{p}<0.01)$ different from 0 to $30^{\text {th }}$ day post-partum, and its highest and lowest values were observed on 0 day and $45^{\text {th }}$ day, respectively. NEFA values were significant $(\mathrm{p}<0.01)$ during the post-partum period. NEFA concentration was significantly $(p<0.01)$ higher in the control group as compared to treatment group where it showed a decreasing trend from 0 to $45^{\text {th }}$ day post-partum. Glucose concentration decreased from the day of kidding until $14^{\text {th }}$ day post-partum followed by an increased up to $45^{\text {th }}$ day post-partum. As compared to treatment group significant $(p<0.01)$ differences in glucose values were seen in control group wherein it was lower on the day of kidding and higher on the $7^{\text {th }}$ and $14^{\text {th }}$ day. Urea concentration was lowest on the day of kidding to highest on $45^{\text {th }}$ day post-partum. Values of urea concentration on the $14^{\text {th }}$ day of post-partum were similar to values in the control group.

The values of some biochemical parameters in both the group (especially on some post-partum days of treatment group) were slightly lower or higher than that of the normal range. The variation could be due to stress on the day of kidding and during the post-partum period.

\section{Discussion}

A significantly lower $\mathrm{Hb}$ concentration was observed on the day of kidding which subsequently increased significantly up to $45^{\text {th }}$ day of lactation. Increase in $\mathrm{Hb}$ during the post-partum period may be due to higher demand of oxygen and requirement of higher metabolic rate [4]. Increase in Hb during the post-partum period has been reported [5]. Nonsignificant difference on 0 day and 7 days after kidding have been reported by Rejitha and Karthiayini [6] in
Malabari goats, -3 to +3 weeks of kidding by Tharwat et al., [7].

Increasing trend in PCV was observed from 0 to 45 days post-partum. Decrease in PCV on the day of parturition has also been reported by Tharwat et al., [7]. The decrease in PCV on the day of parturition has been associated with stress related to parturition [8]. The decrease in PCV on the day of parturition may be attributed to hemodilution effect resulting from an increase in plasma volume or increased water mobilization to mammary gland through the vascular system [9]. However decreases in PCV up to $3^{\text {rd }}$ week of post-partum have been observed by Iriadam [10], while decrease in PCV during both late pregnancy and early lactation has also been reported by Araz [11].

The present study revealed non-significant difference during post-partum period in TEC that are in agreement to that reported by Rejitha and Karthiayini [6]. In general, red cell parameters decrease during gestation and remain low for a few weeks post-partum as has been observed in cows, mares, sows, ewes, and bitches [12]. However, a great variation in hematological parameters exists between various breeds of goat [13].

Significantly $(p<0.01)$ low value of TLC was observed on 0 day and values on $7^{\text {th }}$ to $45^{\text {th }}$ day post-partum differed non-significantly. Lowest TLC was found on the day of kidding that may be due to low immunity or stress. A significant difference in lymphocyte, MID \% (mid-sized cells), and granulocyte \% was observed on the $0-45$ days in the present study. The present finding of increase in granulocyte on the day of kidding are similar to the findings of Iriadam [10]. Granulocyte to lymphocyte ratio increase during the post-partum period which may be attributed to stress that stimulates secretion of adrenocorticotropic hormone which in turn induces the 


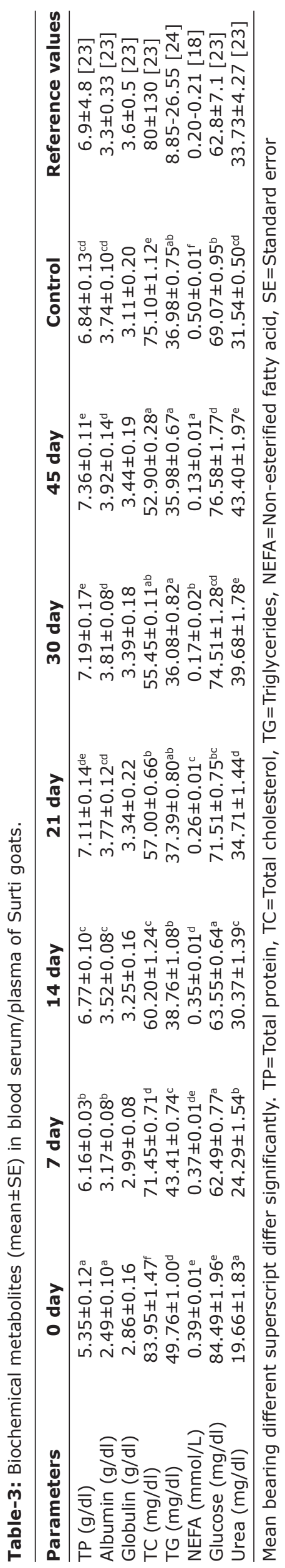

adrenal cortex to produce glucocorticoids, involved in the mobilization of granulocytes from body pool into the peripheral circulation [14]. In the present study also the ratio of granulocyte: Lymphocyte was highest on the day of kidding.

TP and albumin concentration increased significantly $(\mathrm{p}<0.01)$ from 0 to 14 days as well as on $45^{\text {th }}$ day post-partum while the difference was non-significant for globulin. TP increased during the post-partum period that may be because of increase in globulin resulting from the formation of immunoglobulin. The finding of the present study of the increase in TP and globulin in post-partum are similar to that of Tharwat et al., [7]. Increase in TP but non-significant decrease in albumin in $3^{\text {rd }}$ week after parturition has also been reported by Iriadam [10]. Increase in albumin in $1^{\text {st }}$ week followed by decrease in $2^{\text {nd }}$ week post-partum has been reported during post-partum Iriadam [10].

A significant $(p<0.01)$ difference was observed from 0 to $30^{\text {th }}$ day post-partum in the levels of TG. High TG concentration during the $1^{\text {st }}$ week before parturition followed by a significant decrease on 2 days post-partum has been reported by Skotnicka et al., [15]. The onset of lactation has significant effect on TG as well as cholesterol concentration. During the lactation period, lipogenesis and esterification are reduced, and free fatty acid mobilization is stimulated by an increase in nor-epinephrine and epinephrine secretion. The activity of lipoprotein lipase is increased in mammary gland and decreased in adipose tissue. However, contradictory results of lowest TG on the day of kidding as compared to present findings were reported by Sadjadian et al., [16]. Decrease in TG concentration during the lactation period may be due to catabolism of TG for the supply of energy for milk synthesis.

NEFA values were significantly different $(p<0.01)$ during the post-partum period. Decreasing trend was observed from 0 to $45^{\text {th }}$ day post-partum. Peak level of NEFA concentration on the day of kidding followed by decrease up to $45^{\text {th }}$ days are in agreement to that of Sadjadian et al., [16] in Saanen does. The increase in NEFA concentration at the time of parturition may be due to high energy requirement for parturition. Increase in plasma lipolytic hormones prior to parturition may be contributing to increasing plasma NEFA concentration. Increase in NEFA indicates a deficit in energy intake due to the mobilization of fat and increase in free fatty acid. The decrease in NEFA concentration was found to be significantly decreasing during different weeks. Elevated plasma concentration of NEFA occurs simultaneous to increased rate of lipolysis in adipose tissue and has been reported in goats during late pregnancy and early lactation [17]. Blood concentration of NEFA is linked to energy balance and $0.20-0.21 \mathrm{mmol} / \mathrm{L}$ NEFA concentration has been suggested for lactating does at zero energy balance [18]. Plasma concentrations of NEFA may be possible diagnostic markers of impaired immunity and a higher risk of infections around parturition [19]. 
Table-4: Analysis of variance for biochemical metabolites.

\begin{tabular}{lccccccccc}
\hline $\begin{array}{l}\text { Source of } \\
\text { variation }\end{array}$ & df & \multicolumn{7}{c}{ Mean sum of square } \\
\cline { 2 - 9 } & & TP & Albumin & Globulin & TC & TG & NEFA & Glucose & Urea \\
\hline Treatment & 6 & $9.99 * *$ & $5.09 * *$ & 0.95 & $2757.37 * *$ & $518.48^{* *}$ & $0.34 * *$ & $1177.74 * *$ & $1369.92 * *$ \\
Error & 133 & 0.29 & 0.21 & 0.63 & 17.13 & 14.36 & 0.00 & 31.73 & 48.56 \\
\hline
\end{tabular}

$* * \mathrm{p}<0.01$. TP=Total protein, $\mathrm{TC}=$ Total cholesterol, $\mathrm{TG}=$ Triglycerides, NEFA=Non-esterified fatty acid, SE=Standard error

Peak level of glucose on the day of kidding was followed by a decrease during $2^{\text {nd }}$ week post-partum. Similar findings are reported by Sadjadian et al., [16]. Increase in glucose concentration on the day of parturition may be due to metabolic changes toward gluconeogenesis [20] and hormonal changes at parturition that promote gluconeogenesis and glycogenolysis [21]. High level of glucose on the day of kidding indicates animals were in positive energy balance. The calorie protein ratio was higher on 0 day as compared to $7^{\text {th }}$ and $14^{\text {th }}$ day. Increase in glucose may also be due to lower concentration of insulin. Decreasing blood glucose concentration during first 2 weeks of lactation appears to be related to high energy demand especially in high milk producing breeds of goats and increasing glucose concentration after the $2^{\text {nd }}$ week of lactation may be due to the recovery of feed intake and decreasing negative energy balance. At the time of parturition, glucocorticoids and estradiol concentration reaches the peak level and even the insulin response. A significant increase in glucocorticoid causes liver glycogenolysis and mobilization of amino acid for gluconeogenesis. The decrease blood glucose with the advancement of days of lactation may be attributed to the synthesis of lactose with increased milk production [21].

Urea concentration increased significantly $(p<0.01)$ from 0 to $45^{\text {th }}$ day post-partum. High level of blood urea nitrogen (BUN) on the $21^{\text {st }}$ day post-partum and lowest level on the day of kidding has been reported [16]. The decrease in serum BUN around parturition may be associated with the decline in feed intake due to stress and hormonal changes during the kidding. Similar findings of a significant increase in BUN during the post-partum period have been reported in different goat breeds [16].

\section{Conclusion}

Hematobiochemical parameters are indicative of health status of Surti goats. Even though hematological parameters measured were in normal range, significantly low values of $\mathrm{Hb}, \mathrm{PCV}$, and TLC during first 2 weeks as compared to the control group are indicative of stress. Parturition and post-partum stress led to wider variations in biochemical parameters as compared to normal range. TP and urea increased parallel to one another during the post-partum period. Catabolism of protein takes place during the first 2 weeks post-partum. Decrease TGs and increase in NEFA during the transition period are suggestive of utilization of lipids for the supply of energy. High glucose level on 0 day indicates that the animals were in positive energy status.

\section{Authors' Contributions}

SSC designed and supervised the experiment. TDM conducted the experiment and also with the help of VKS and SBP conducted the laboratory analysis of the samples. TDM along with SSC analyzed the data and prepared the manuscript. SSC, GP, VKS, SBP, and TDM reviewed the manuscript. All authors read and approved the final manuscript.

\section{Acknowledgments}

The authors are highly thankful to the Dean, Vanbandhu College of Veterinary Science and A.H. for financial assistance and research facilities to conduct this experiment. The authors also thank Research Scientist, Livestock Research Station, NAU and Project Incharge of AICRP on goat improvement Surti field unit at LRS, NAU Navsari for the availability of experimental animals.

\section{Competing Interests}

The authors declare that there is no conflict of interests regarding the publication of this paper.

\section{References}

1. Gupta, V.K., Kumar, A., Vihan, V.S. and Sharma, S.D. (2008) Studies on hemogram in sub clinical ketosis in goat and sheep in organized farming system. Indian J. Anim. Sci., 14(1): 971-973.

2. Karapehlivan, M., Atakisi, E., Atakisi, O., Yucart, R. and Pancarci, S.M. (2007) Blood biochemical parameters during the lactation and dry period in Tuj ewes. Small Rumin. Res., 73: 267-271.

3. Snedecor, G.W. and Cochran, W.G. (1994) Statistical Methods. $8^{\text {th }}$ ed. Iowa State University Press, United States of America.

4. Antunovic, Z., Novoselec, J., Sauerwein, H., Speranda, M., Vegara, M. and Pavic, V. (2011) Blood metabolic profile and some of hormones concentration in ewes during different physiological status. Bulg. J. Agric. Sci., 17(5): 687-695.

5. Kaushish, S.K., Karim, S.A. and Rawat, P.S. (2000) Blood biochemical changes during lactation in different breeds of goat. Indian J. Anim. Sci., 70(5): 494-496.

6. Rejitha, J. and Karthiayini, K. (2014) Haematological profile of crossbred Malabari goats in peripartum period. IOSR-JAVS., 7(6): 43-44.

7. Tharwat, M., Ali, A. and Al-Sobayil, F. (2013) Hematological and biochemical profiles in goats during the transition period. Comp. Clin. Pathol., 24: 1-7.

8. El-Ghoul, W., Hofmann, W., Khamis, Y. and Hassanein, A. (2000) Relationship between claw disorders and the peripartal period in dairy cows. Prakt. Tierarzt., 81(10): 862-868.

9. El-Sherif, M.M.A. and Assad, F. (2001) Change in some blood constituents of Barki ewes during pregnancy and 
lactation under semi-arid conditions. Small Rumin. Res., 40: 269-277.

10. Iriadam, M. (2007) Variation in certain hematological and biochemical parameters during the peri-partum period in Kilis does. Small Rumin. Res., 73(1): 54-57.

11. Araz, O.B. (2013) Changes in Some haematobiochemical and electrolytes parameters in female meriz goats during pregnancy and after parturition. J. Anim. Sci., 2(1): 11-14.

12. Jain, N.C. (1993) Essentials of Veterinary Hematology. $1^{\text {st }}$ ed. Wiley, Philadelphia. p1-18.

13. Anwar, M.M., Ramadan, T.A. and Taha, T.A. (2012) Serum metabolites, milk yield, and physiological responses during the first week after kidding in Anglo-Nubian, Angora, Baladi, and Damascus goats under subtropical conditions. J. Anim. Sci., 90: 4795-4806.

14. Adenkola, A., Ayo, J.O., Sackey, A.K.B. and Adelaiye, A.B. (2011) Eight hours road transportation and ascorbic acid administration effects on hematological parameters of pigs during the harmattan season. Agric. Biol. J. N. Am., 2(8): 1143-1150.

15. Skotnicka, E., Zbigniew, M. and Maria, S. (2011) Effect of the periparturient period on serum lipid and cholesterol lipoprotein concentrations in goats (Capra hircus). Acta. Vet. Hung., 59(4): 445-454.

16. Sadjadian, R., Seifi, H.A., Mohri, M., Naserian, A.A. and Farzaneh, N. (2013) Variations of energy biochemical metabolites in periparturient dairy Saanen goats. Comp. Clin. Pathol., 22: 449-456.

17. Mabon, R.M., Brechany, E.Y. and Vernon, R.G. (1982)
Plasma unesterified fatty acid and triacylglycerol concentration of the goat (Capra hircus) during pregnancy and lactation. Comp. Biochem. Physiol. B Comp. Biochem., 72: 453-455.

18. Dunshea, F.R., Bell, A.W. and Trigg, T.E. (1989) Relations between plasma non-esterified fatty acid metabolism and body fat mobilization in primiparous lactating goats. $B r . J$. Nutr., 62(01): 51-61.

19. Ospina, P.A., Nydam, D.V., Stokol, T. and Overton, T.R. (2010) Evaluation of nonesterified fatty acids and $\beta$-hydroxybutyrate in transition dairy cattle in the northeastern United States: Critical thresholds for prediction of clinical diseases. J. Dairy Sci., 93: 546-554.

20. Vazquez-Anon, M., Bertics, S., Luck, M., Grummer, R.R. and Pinheiro, J. (1994) Peripartum liver triglyceride and plasma metabolites in dairy cows. J. Dairy Sci., 77(6): $1521-1528$

21. Herdt, T.H. (1988) Fuel homeostasis in the ruminant metabolic diseases of ruminant livestock. Vet. Clin. N. Am. Food Anim. Pract., 4: 213-231.

22. Weiss, D.J. and Wardrop, K.J. (2011) Schalm's Veterinary Hematology. $6^{\text {th }}$ ed. John Wiley and Sons, New York.

23. Kaneko, J.J., Harvey, J.W. and Bruss, M.L. (2008) Clinical Biochemistry of Domestic Animals. $6^{\text {th }}$ ed. Harcourt Brace and Company Asia PVT Ltd., Academic Press, Singapore.

24. Bagnicka, E., Jarczak, J., Kosciuczuk, E., Kaba, J. and Jozwik, A. (2014) Active dry yeast culture supplementation effect on the blood biochemical indicators of dairy goats. $J$. Adv. Dairy Res., 2: 123.

\section{$* * * * * * * *$}

